\title{
Kinetic Spectrophotometric Determination of Certain Cephalosporins in Pharmaceutical Formulations
}

\author{
Mahmoud A. Omar, Osama H. Abdelmageed, and Tamer Z. Attia \\ Analytical Chemistry Department, Faculty of Pharmacy, Minia University, 61519 Minia, Egypt \\ Correspondence should be addressed to Mahmoud A. Omar, momar1971g@yahoo.com
}

Received 4 August 2008; Accepted 16 March 2009

Recommended by Manuel P. Soriaga

\begin{abstract}
A simple, reliable, and sensitive kinetic spectrophotometric method was developed for determination of eight cephalosporin antibiotics, namely, Cefotaxime sodium, Cephapirin sodium, Cephradine dihydrate, Cephalexin monohydrate, Ceftazidime pentahydrate, Cefazoline sodium, Ceftriaxone sodium, and Cefuroxime sodium. The method depends on oxidation of each of studied drugs with alkaline potassium permanganate. The reaction is followed spectrophotometrically by measuring the rate of change of absorbance at $610 \mathrm{~nm}$. The initial rate and fixed time (at 3 minutes) methods are utilized for construction of calibration graphs to determine the concentration of the studied drugs. The calibration graphs are linear in the concentration ranges 5$15 \mu \mathrm{g} \mathrm{mL} \mathrm{m}^{-1}$ and $5-25 \mu \mathrm{g} \mathrm{mL} \mathrm{m}^{-1}$ using the initial rate and fixed time methods, respectively. The results are validated statistically and checked through recovery studies. The method has been successfully applied for the determination of the studied cephalosporins in commercial dosage forms. Statistical comparisons of the results with the reference methods show the excellent agreement and indicate no significant difference in accuracy and precision.
\end{abstract}

Copyright (C) 2009 Mahmoud A. Omar et al. This is an open access article distributed under the Creative Commons Attribution License, which permits unrestricted use, distribution, and reproduction in any medium, provided the original work is properly cited.

\section{Introduction}

Cephalosporins consist of a fused $\beta$-lactam- $\Delta 3$-dihydrothiazine two-ring system, known as 7 -aminocephalosporanic acids (7-ACAs) and vary in their side chain substituents at $\mathrm{C} 3$ (R2) and C7 (acylamido, R1). The chemical structure of the studied cephalosporins in this work is shown in Table 1. They are used for treatment of infection caused by both gramnegative and gram-positive bacteria $[1,2]$. A wide variety of analytical methods have been reported for determination of cephalosporins in pure form, in pharmaceutical preparations, and in biological fluids. These methods include spectrophotometry [2-5], atomic absorption spectrophotometry [6], fluorometry [7-12], liquid chromatography [13-20], Micellar electrokinetic capillary chromatography [21, 22], chemiluminescence [23-28], potentiometric $[29,30]$, and polarographic [31-34] methods. Kinetic spectrophotometric methods became of great interest in chemical and pharmaceutical analyses [35]. The literature is still poor in analytical procedure based on kinetics, especially for determination of drug in commercial dosage forms. We aimed to improve on the current methods by employing the kinetic colorimetric oxidation of cephalosporins to increase selectivity, avoid interference of colored and/or turbidity background of samples and consequently determination of low concentration of the cited drugs as possible.

\section{Experimental}

2.1. Apparatus. Spectronic Genesys 2PC. Ultraviolet/Visible spectrophotometer (Milton Roy Co, USA) with matched $1 \mathrm{~cm}$ quartz cell was used for all measurements connected to IBM computer loaded with winspec application software.

2.2. Materials and Reagents. All the materials were of analytical reagent grade, and the solutions were prepared with double-distilled water. Samples of cephalosporin were generously supplied by their respective manufacturers and were used without further purification.

(i) Cephalexin monohydrate, Ceftazedime pentahydrate, and Cefuroxime sodium (Galaxowelcome Egypt, S.A.E, El Salam City, Cairo, Egypt).

(ii) Cephapirin sodium, Cefazoline sodium (Bristol Myers- Squib Pharmaceutical Co., Cairo, Egypt). 
TABLE 1: Structural formula of the studied cephalosporins.

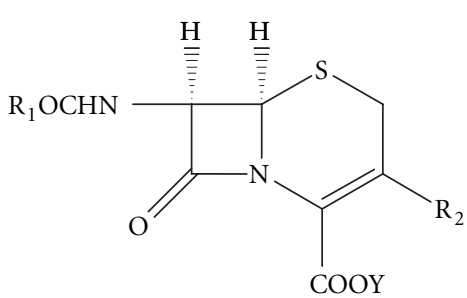

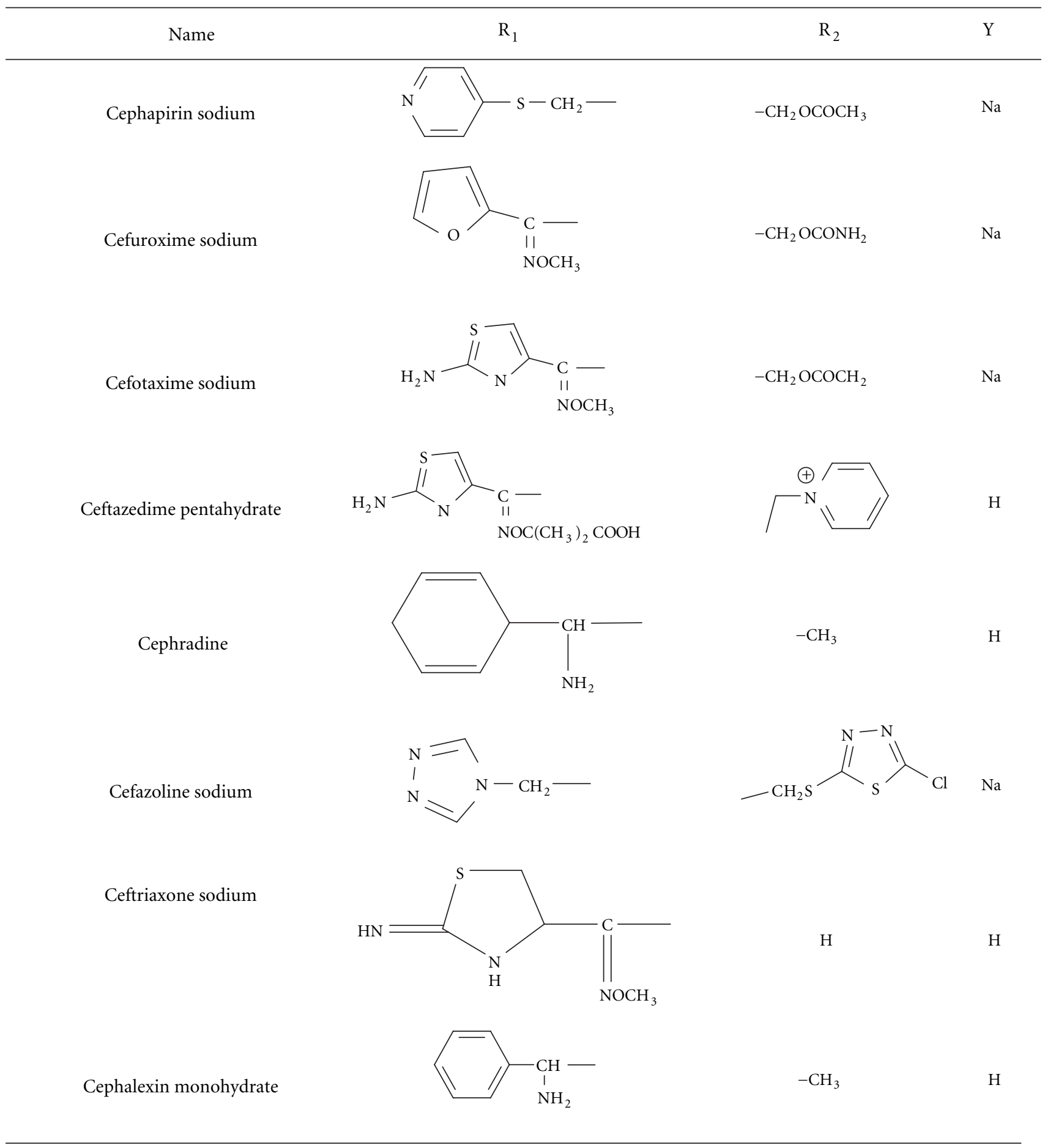


(iii) Cefotaxime sodium, cephradine, and Ceftriaxone sodium (EIPICO, Tenth of Ramadan City, Cairo, Egypt).

The purity of authentic samples was checked by UV assay methods and was not less than $99.26 \pm 0.72$.

(i) Potassium permanganate (Merck, Germany); $6 \times 10^{-3}$ Molar solution was prepared by dissolving $100 \mathrm{mg}$ in $100 \mathrm{~mL}$ of double-distilled water followed by boiling and filtration through sintered glass.

Potassium permanganate solution should be freshly prepared and its molarity was checked titrimetrically.

(i) Sodium hydroxide (El Nasr chemical co., Abuo Zabbel, Egypt); $0.75 \mathrm{M}$ prepared by dissolving $3 \mathrm{~g}$ in $100 \mathrm{~mL}$ of double-distilled water.

(ii) Methanol (Merck, Darmstadt, Germany).

2.3. Pharmaceutical Formulations. The following available commercial preparations were analyzed.

Ceporex tablets and vials, Fortam vials and Zinnat vials (Galoxowelcome Egypt, S.A.E, El Salam City, Cairo, Egypt), labeled to contain $250 \mathrm{mg}$ cephalexin monohydrate per tablet and $500 \mathrm{mg}$ cephalexin sodium equivalent to $500 \mathrm{mg}$ cephalexin monohydrate per vial, $250 \mathrm{mg}$ ceftazidime pentahydrate per vial, and $250 \mathrm{mg}$ cefuroxime sodium per vial, respectively. Cefatrexyl vials, Totacef vials and Velosef tablets and suspensions (Bristol Myers-Squibb Pharmaceutical Co., Cairo, Egypt), labeled to contain $500 \mathrm{mg}$ cephapirin sodium per vial, $500 \mathrm{mg}$ cefazoline sodium per vial, and $500 \mathrm{mg}$ cephradine per tablet and suspensions, respectively. Cefotax vials (EIPICO. Tenth of Ramadan City, Cairo, Egypt), labeled to contain $250 \mathrm{mg}$ cefotaxime sodium per vial. Ceftriaxone vials (Novartis Pharma S.A.E, Cairo, Egypt), labeled to contain $500 \mathrm{mg}$ ceftriaxone sodium per vial.

2.4. Preparation of Standard Solution. Stock solution containing $1 \mathrm{mg} \mathrm{mL}^{-1}$ of each cephalosporins was prepared in double-distilled water, working standard solutions containing $100 \mu \mathrm{g} \mathrm{mL}^{-1}$ were prepared by suitable dilution of the stock solutions with double-distilled water.

\subsection{Recommended Procedure for Cephalosporins \\ Determination}

2.5.1. Initial Rate Method. Aliquots of $50-150 \mu \mathrm{g} \mathrm{mL}^{-1}$ of studied cephalosporins test solutions were pipetted into a series of $10 \mathrm{~mL}$ volumetric flask. $1.2 \mathrm{~mL}$ of sodium hydroxide solution $(0.75 \mathrm{M})$ was added followed by $3.0 \mathrm{~mL}$ of potassium permanganate solution $\left(6 \times 10^{-3} \mathrm{M}\right)$ to each flask and then diluted to the volume with double-distilled water at $30 \pm 1{ }^{\circ} \mathrm{C}$. The content of mixture of each flask was mixed well and the increase in absorbance at $610 \mathrm{~nm}$ was recorded as a function of time for 15 minutes against reagent blank treated similarly. The initial rate of the reaction $(v)$ at different concentrations was obtained from the slope of the tangent to absorbance time curves. The calibration graphs were constructed by plotting the logarithm of the initial rate of the reaction $(\log v)$ versus logarithm of molar concentration of the studied drugs $(\log C)$.

2.5.2. Fixed Time Method. In this method, the absorbance of each sample solution at preselected fixed time ( 3 minutes) was accurately measured and plotted against the final concentration of the drug.

\subsection{Determination of the Studied Drugs in Pharmaceutical Formulations}

2.6.1. Procedure for Tablets. An accurately weighed amount equivalent to $100.0 \mathrm{mg}$ of each drug from composite of 20 powdered tablets was transferred into a $100 \mathrm{~mL}$ volumetric flask. Dissolved in about $20 \mathrm{~mL}$ methanol, swirled, and sonicated for 10 minutes, the resultant mixture was filtered into round bottom flask for removal of any pharmaceutically "inert" ingredients (cellulose, disaccharides) that could be subject to oxidation by permanganate. The residue was washed thoroughly with about $5 \mathrm{~mL}$ methanol and the combined filtrate as well as washing solutions was subjected to evaporation under vacuum till dryness. The residue lifted was dissolved in about $20 \mathrm{~mL}$ distilled water and filtered into $100 \mathrm{~mL}$ volumetric flask. The filter paper was washed thoroughly with double distilled water, and then the combined filtrate as well as washing solutions was mixed well and completed to volume with the same solvent to obtain solution of $1.0 \mathrm{mg} \mathrm{mL}^{-1}$. The final solution was diluted quantitatively with the same solvent to obtain working standard solution of $100.0 \mu \mathrm{g} \mathrm{mL} L^{-1}$, then the general procedure was followed.

2.6.2. Procedure for Capsules and Suspension. The contents of 20 capsules were evacuated and well mixed. Then an accurately weighed amount equivalent to $100.0 \mathrm{mg}$ evacuated capsules or dry powder suspension of each drug was transferred into a $100 \mathrm{~mL}$ beaker, and then the procedure was continued as described under tablets.

2.6.3. Procedure for Vials. A $100.0 \mathrm{mg}$ quantity of each vial was transferred into a $100 \mathrm{~mL}$ volumetric flask, dissolved, and completed to the mark with double-distilled water to obtain solution of $1.0 \mathrm{mg} \mathrm{mL}^{-1}$. Further dilutions with double-distilled water were made to obtain sample solutions $\left(100.0 \mu \mathrm{g} \mathrm{mL}^{-1}\right)$, then the general procedure was followed.

\section{Results and Discussion}

Potassium permanganate as strong oxidizing agent has been used in oxidimetric analytical method for determination of many compounds [36-39]. During the course of the reaction, the valence of manganese changes. The heptavalent manganese ion changes to the green color (Mn VI), while in neutral and acidic medium, the permanganate is further reduced to colorless (Mn II). The behavior of permanganate was the basis for its uses in development of spectrophotometric method. The absorption spectrum of aqueous potassium permanganate solution in alkaline 


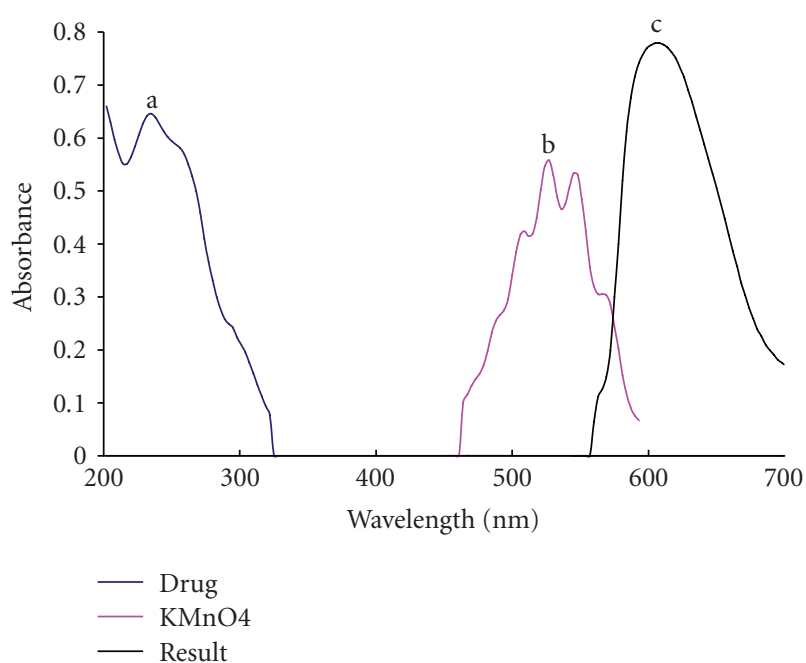

Figure 1: Absorption spectra of (a) alkaline potassium permanganate $\left(6 \times 10^{-3} \mathrm{M}\right)$ (b) cefotaxime $\left(15 \mu \mathrm{g} \mathrm{mL} \mathrm{m}^{-1}\right)$ and (c) the reaction product.

medium exhibited an absorption band at $530 \mathrm{~nm}$. The additions of any of the studied drugs to this solution produce a new characteristic band at $610 \mathrm{~nm}$ (Figure 1). This band is due to formation of manganate ion, which resulted from the oxidation of cephalosporin by potassium permanganate in alkaline medium. The intensity of the color increases with time; therefore a kinetically based method was developed for determination of cephalosporins in their pharmaceutical dosage formulations. The different variables that affect the formation of manganate ion were studied and optimized.

3.1. Effect of Potassium Permanganate Concentration. The absorbance increases substantially with increasing the concentration of potassium permanganate (Figure 2). Maximum absorbance was obtained when $2.5 \mathrm{~mL}$ of $6 \times 10^{-3} \mathrm{M}$ of potassium permanganate was used. Thus, the adoption of $3 \mathrm{~mL}$ of potassium permanganate in the final solution proved to be adequate for the maximum concentration of cephalosporin used in determination process (the concentration of the final assay was $1.8 \times 10^{-3} \mathrm{M}$ ).

3.2. Effect of Sodium Hydroxide Concentration. Maximum absorption was obtained when $1 \mathrm{~mL}$ of $0.75 \mathrm{M} \mathrm{NaOH}$ was used. Over this volume no change in absorbance could be detected. So $1.2 \mathrm{~mL}$ of $0.75 \mathrm{M}$ of $\mathrm{NaOH}$ was used as an optimum value (Figure 3 ).

3.3. Effect of Temperature. At room temperature the reaction rate increases substantially with time, although heating the solution was found to increase the rate of the reaction however but $\mathrm{MnO}_{2}$ was precipitated, therefore room temperature was selected as the optimum temperature.

3.4. Stoichiometry and Reaction Mechanism. The stoichiometric ratio between potassium permanganate and each of investigated cephalosporins was determined by Job's method

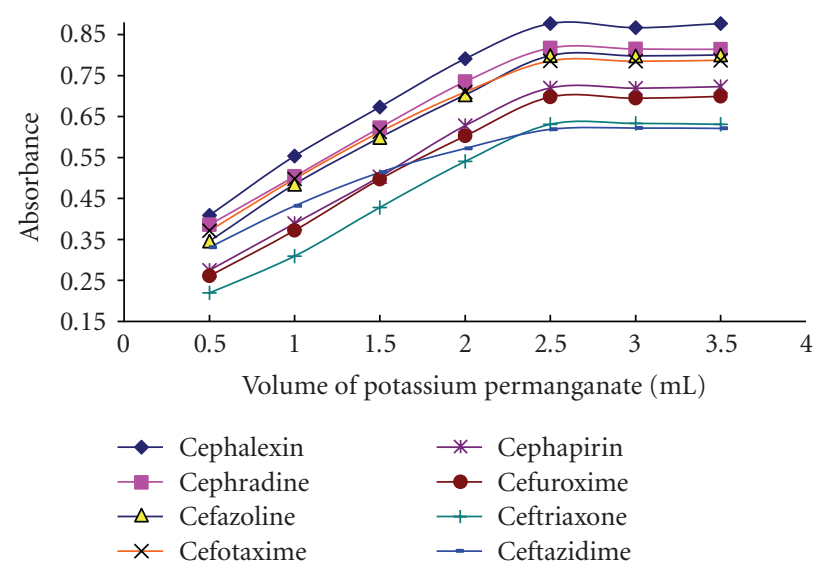

FIGURE 2: Effect of potassium permanganate $\left(3 \times 10^{-6}\right)$ on the reaction between the investigated cephalosporins $\left(15 \mu \mathrm{g} \mathrm{mL}^{-1}\right)$ and alkaline potassium permanganate.

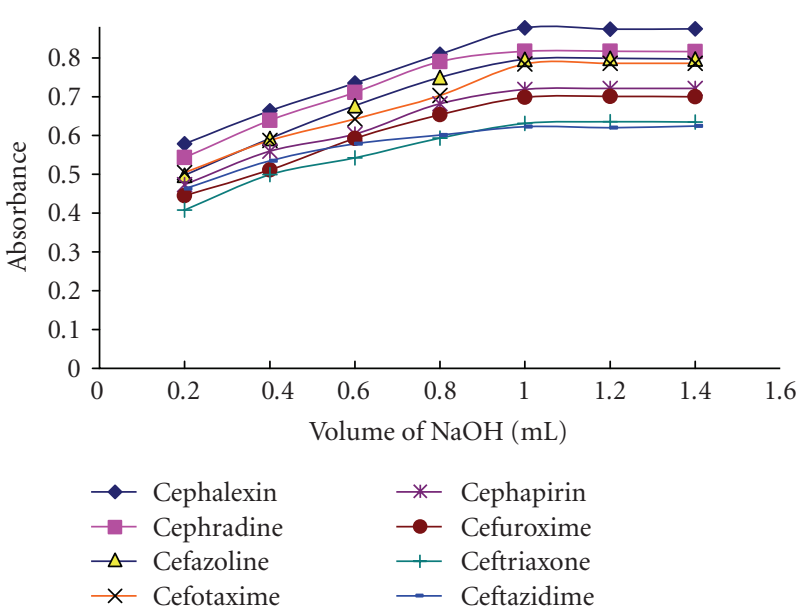

Figure 3: Effect of sodium hydroxide concentration $(0.75 \mathrm{M})$ on the reaction between the investigated cephalosporins $\left(15 \mu \mathrm{g} \mathrm{mL}^{-1}\right)$ and alkaline potassium permanganate.

$[40,41]$ and was found to be $1: 1$ (Figure 4). Cephalosporins were found to be susceptible for oxidation with alkaline potassium permanganate producing a green color peaking at $610 \mathrm{~nm}$. Therefore, the reaction mechanism is proposed on the basis of the literature background (39) and our experimental study as shown in Scheme 1 .

The opening of the $\beta$-lactam ring by the hydroxyl ion proceeds via intermediate and result in the formation of cephalosporoic acid and the intermediate formation is the rate limiting step.

3.5. Kinetic of the Reaction. Under the optimum conditions, the absorbance time curves of investigated cephalosporins with potassium permanganate reagent were constructed (Figures 5, 6 for cefotaxime as a representative example). The initial rate of the reaction was determined from the slope of tangents of the absorption time curves. The order of the reaction with respect to permanganate was determined by studying the reaction at different concentrations 


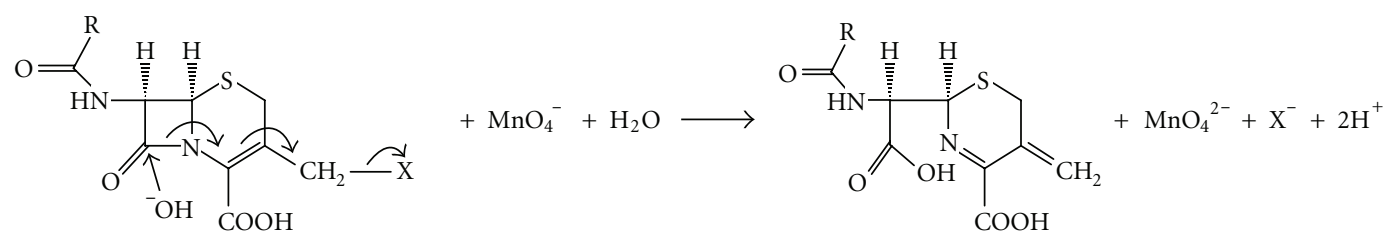

Scheme 1

TABLe 2: Analytical parameters for the initial rate method for determination of investigated cephalosporins with alkaline potassium permanganate.

\begin{tabular}{|c|c|c|c|c|c|}
\hline \multirow[t]{2}{*}{ Investigated cephalosporin } & \multirow{2}{*}{$\begin{array}{l}\text { Linear range, } \\
\mathrm{M} \times 10^{-5} \\
\left(\mu \mathrm{g} \mathrm{mL}^{-1}\right)\end{array}$} & \multicolumn{2}{|c|}{$\begin{array}{c}\text { Least square equation } \\
\log V=\log K^{\prime}+n \log C\end{array}$} & \multirow{2}{*}{$\begin{array}{c}\text { Correlation } \\
\text { coefficient } \\
(r)\end{array}$} & \multirow[t]{2}{*}{$\mathrm{LOD} \mu \mathrm{g} \mathrm{mL}^{-1}$} \\
\hline & & Intercept $\left(\log K^{\prime}\right)$ & Slope $(n)$ & & \\
\hline Cefotaxime & $\begin{array}{c}1.04 \text { to } 3.14 \\
(5-15)\end{array}$ & 1.918 & 1.007 & 0.9999 & 0.121 \\
\hline Cephapirin & $\begin{array}{c}1.18 \text { to } 3.54 \\
\quad(5-15)\end{array}$ & 1.866 & 1.010 & 0.9999 & 0.117 \\
\hline Cephradine & $\begin{array}{c}1.43 \text { to } 4.29 \\
(5-15)\end{array}$ & 1.788 & 0.9942 & 0.9997 & 0.162 \\
\hline Cephalexin & $\begin{array}{c}1.43 \text { to } 4.31 \\
(5-15)\end{array}$ & 1.856 & 1.001 & 0.9996 & 0.19 \\
\hline Ceftazidime & $\begin{array}{c}0.78 \text { to } 2.33 \\
\quad(5-15)\end{array}$ & 2.044 & 1.046 & 0.9995 & 0.233 \\
\hline Cefazoline & $\begin{array}{l}1.1 \text { to } 3.3 \\
(5-15)\end{array}$ & 1.832 & 0.9918 & 0.9992 & 0.28 \\
\hline Ceftriaxone & $\begin{array}{c}0.9 \text { to } 2.7 \\
(5-15)\end{array}$ & 1.884 & 1.009 & 0.9994 & 0.241 \\
\hline Cefuroxime & $\begin{array}{c}1.17 \text { to } 3.53 \\
(5-15)\end{array}$ & 1.985 & 1.045 & 0.9996 & 0.209 \\
\hline
\end{tabular}

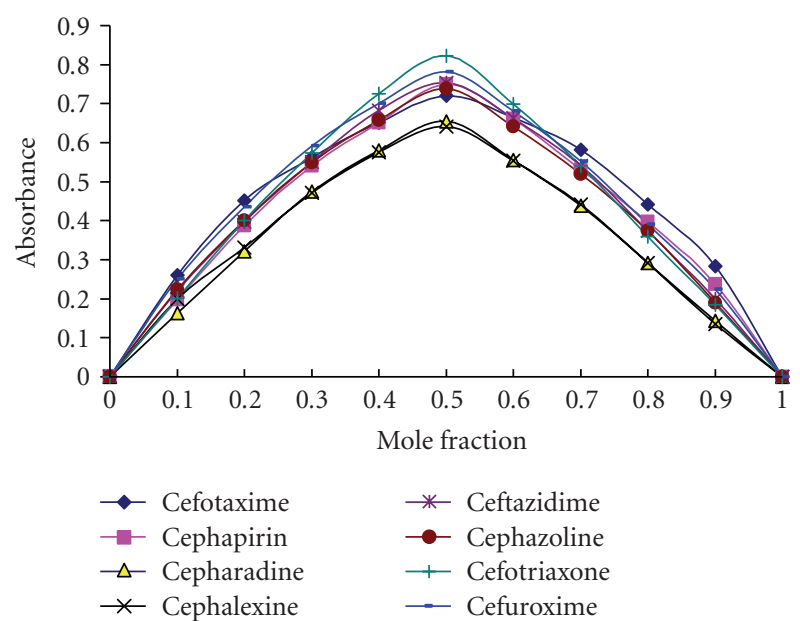

FIGURE 4: Job's plots of continuous variation between potassium permanganate and the studied drugs.

of permanganate with fixed concentration of investigated cephalosporins. The plot of initial rate $(\Delta A / \Delta t)$ against initial absorbance was linear passing through origin indicating that the initial order of the reaction with respect to permanganate was 1 . The order with respect to investigated cephalosporins was evaluated by measuring the rate of the reaction at several concentrations of cephalosporins at a fixed concentration of permanganate reagent. This was done by plotting the logarithm of initial rate of the reaction versus logarithm of molar concentration of investigated cephalosporins and was found to be 1 . However under the optimized experimental conditions, the concentrations of cephalosporins were determined using relative excess amount of potassium permanganate and sodium hydroxide solutions. Therefore pseudo-zero-order conditions were obtained with respect to their concentrations.

\subsection{Quantitation Methods}

3.6.1. Initial Rate Method. The initial rate of the reaction would follow pseudo-first-order and were found to obey the following equation:

$$
v=\frac{\Delta A}{\Delta t}=K^{\prime} C^{n}
$$

where $v$ is the reaction rate, $A$ is the absorbance, $t$ is the measuring time, $K^{\prime}$ is the pseudo-first-order rate constant, $C$ is the molar concentration of cephalosporins, and $n$ is the 
TABle 3: Analytical parameters for fixed time method of the kinetic spectrophotometric parameter for determination of investigated cephalosporins.

\begin{tabular}{|c|c|c|c|c|c|c|c|}
\hline $\begin{array}{l}\text { Reaction } \\
\text { time }\end{array}$ & $\begin{array}{l}\text { Linear } \\
\text { range } \\
\left(\mu \mathrm{gL}^{-1}\right)\end{array}$ & Intercept $(a)$ & $\begin{array}{l}\text { Standard } \\
\text { deviation of } \\
\text { intercept }\left(S_{a}\right)\end{array}$ & Slope $(b)$ & $\begin{array}{l}\text { Standard } \\
\text { deviation of } \\
\text { slope }\left(S_{b}\right)\end{array}$ & $\begin{array}{l}\text { Correlation } \\
\text { coefficient }(r)\end{array}$ & $\mathrm{LOD}\left(\mu \mathrm{g} \mathrm{mL}^{-1}\right)$ \\
\hline \multicolumn{8}{|c|}{ Cefotaxime } \\
\hline 3 & $5-25$ & 0.00568 & 0.005827 & 0.02845 & 0.0003607 & 0.9993 & 0.6144 \\
\hline 6 & $5-19$ & 0.01698 & 0.005317 & 0.03472 & 0.0004140 & 0.9996 & 0.4590 \\
\hline 9 & $5-17$ & 0.02618 & 0.005363 & 0.04004 & 0.0004582 & 0.9997 & 0.4018 \\
\hline 12 & $5-17$ & 0.02880 & 0.005112 & 0.04516 & 0.0004368 & 0.9998 & 0.3395 \\
\hline 15 & $5-17$ & 0.01995 & 0.005112 & 0.05102 & 0.0004368 & 0.9998 & 0.3005 \\
\hline \multicolumn{8}{|c|}{ Cephapirin } \\
\hline 3 & $5-25$ & 0.00105 & 0.005027 & 0.02801 & 0.0003088 & 0.9995 & 0.5384 \\
\hline 6 & $5-19$ & 0.03286 & 0.004621 & 0.03176 & 0.0003598 & 0.9996 & 0.4364 \\
\hline 9 & $5-17$ & 0.05639 & 0.003562 & 0.03525 & 0.0003043 & 0.9998 & 0.30314 \\
\hline 12 & $5-17$ & 0.08327 & 0.003653 & 0.03791 & 0.0003121 & 0.9998 & 0.289 \\
\hline 15 & $5-17$ & 0.09054 & 0.003790 & 0.04196 & 0.0003238 & 0.9999 & 0.27097 \\
\hline \multicolumn{8}{|c|}{ Cephradine } \\
\hline 3 & $5-25$ & 0.01464 & 0.009607 & 0.03216 & 0.0005901 & 0.9985 & 0.896 \\
\hline 6 & $5-19$ & 0.02004 & 0.007665 & .03856 & 0.0005967 & 0.9993 & 0.596 \\
\hline 9 & $5-17$ & 0.04891 & 0.005234 & 0.04184 & 0.0004471 & 0.9997 & 0.375 \\
\hline 12 & $5-17$ & 0.06645 & 0.004959 & 0.04566 & 0.0004237 & 0.9998 & 0.3258 \\
\hline 15 & $5-17$ & 0.07721 & 0.005174 & 0.04907 & 0.0004420 & 0.9998 & 0.3163 \\
\hline \multicolumn{8}{|c|}{ Cephalexin } \\
\hline 3 & $5-25$ & 0.01573 & 0.006484 & 0.03518 & 0.0003983 & 0.9994 & 0.5529 \\
\hline 6 & $5-19$ & -0.0067 & 0.007189 & 0.04353 & 0.0005580 & 0.9995 & 0.495 \\
\hline 9 & $5-17$ & -0.0012 & 0.005694 & 0.04841 & 0.0004865 & 0.9997 & 0.3528 \\
\hline 12 & $5-17$ & -0.0040 & 0.005204 & 0.05354 & 0.0004446 & 0.9998 & 0.2915 \\
\hline 15 & $5-17$ & -0.0015 & 0.005412 & 0.05821 & 0.0004624 & 0.9998 & 0.2789 \\
\hline \multicolumn{8}{|c|}{ Ceftazidime } \\
\hline 3 & $5-25$ & -0.0029 & 0.003859 & 0.01905 & 0.0002371 & 0.9993 & 0.6077 \\
\hline 6 & $5-19$ & 0.03039 & 0.004045 & 0.02324 & 0.0003149 & 0.9994 & 0.52216 \\
\hline 9 & $5-17$ & 0.04486 & 0.003966 & 0.02871 & 0.0003388 & 0.9997 & 0.41442 \\
\hline 12 & $5-17$ & 0.06577 & 0.003875 & 0.03270 & 0.0003311 & 0.9997 & 0.3555 \\
\hline 15 & $5-17$ & 0.07993 & 0.003785 & 0.03636 & 0.0003234 & 0.9998 & 0.3128 \\
\hline \multicolumn{8}{|c|}{ Cefazoline } \\
\hline 3 & $5-25$ & 0.00027 & 0.006894 & 0.02935 & 0.0004235 & 0.9991 & 0.70466 \\
\hline 6 & $5-19$ & 0.02604 & 0.006741 & 0.03439 & 0.0005246 & 0.9993 & 0.588 \\
\hline 9 & $5-17$ & 0.03064 & 0.006040 & 0.04064 & 0.0005161 & 0.9996 & 0.4458 \\
\hline 12 & $5-17$ & 0.04073 & 0.005576 & 0.04566 & 0.0004764 & 0.9997 & 0.366 \\
\hline 15 & $5-17$ & 0.03973 & 0.005958 & 0.05038 & 0.0005090 & 0.9997 & 0.3547 \\
\hline \multicolumn{8}{|c|}{ Ceftriaxone } \\
\hline 3 & $5-25$ & -0.0024 & 0.004203 & 0.02274 & 0.0002582 & 0.9994 & 0.55448 \\
\hline 6 & $5-19$ & 0.02739 & 0.004303 & 0.02770 & 0.0003329 & 0.9996 & 0.466 \\
\hline 9 & $5-17$ & 0.01350 & 0.004163 & 0.03307 & 0.0003557 & 0.9997 & 0.377 \\
\hline 12 & $5-17$ & 0.02534 & 0.004423 & 0.03741 & 0.0003779 & 0.9997 & 0.3546 \\
\hline 15 & $5-17$ & 0.03982 & 0.003818 & 0.03939 & 0.0003262 & 0.9998 & 0.2907 \\
\hline
\end{tabular}


TABle 3: Continued.

\begin{tabular}{lllllllc}
\hline $\begin{array}{l}\text { Reaction } \\
\text { time }\end{array}$ & $\begin{array}{l}\text { Linear } \\
\text { range } \\
\left(\mu \mathrm{g} \mathrm{mL} \mathrm{m}^{-1}\right)\end{array}$ & Intercept $(a)$ & $\begin{array}{l}\text { Standard } \\
\text { deviation of } \\
\text { intercept }\left(S_{a}\right)\end{array}$ & Slope $(b)$ & $\begin{array}{l}\text { Standard } \\
\text { deviation of } \\
\text { slope }\left(S_{b}\right)\end{array}$ & $\begin{array}{l}\text { Correlation } \\
\text { coefficient }(r)\end{array}$ & LOD $\left(\mu \mathrm{mL}^{-1}\right)$ \\
\hline & & & & Cefuroxime & & & \\
3 & $5-25$ & -0.0065 & 0.005980 & 0.02629 & 0.0003674 & 0.9991 & 0.68238 \\
6 & $5-19$ & 0.02696 & 0.005472 & 0.02994 & 0.00004260 & 0.9994 & 0.54829 \\
9 & $5-17$ & 0.04286 & 0.005334 & 0.03471 & 0.0004557 & 0.9996 & 0.4610 \\
12 & $5-17$ & 0.05480 & 0.004229 & 0.03845 & 0.0003613 & 0.9998 & 0.32996 \\
15 & $5-17$ & 0.06130 & 0.005614 & 0.04266 & 0.0004796 & 0.9997 & 0.2747 \\
\hline
\end{tabular}

TABLE 4: Evaluation of accuracy of the analytical procedure using initial rate method.

\begin{tabular}{lccr}
\hline Drug & & \multicolumn{2}{c}{ Recovery \%* } \\
$9.0 \mu \mathrm{gL}^{-1}$ & $15.0 \mu \mathrm{g} \mathrm{mL}$ \\
\hline Cefotaxime & $5.0 \mu \mathrm{g} \mathrm{mL}$ & $99.89 \pm 0.6435$ \\
Cephapirin & $99.8 \pm 1.061$ & $100.06 \pm 0.7136$ & $100.22 \pm 0.7661$ \\
Cephradine & $100.29 \pm 1.071$ & $99.68 \pm 0.7181$ & $99.87 \pm 0.6870$ \\
Cephalexin & $100.74 \pm 0.8237$ & $99.98 \pm 0.6211$ & $99.73 \pm 0.4031$ \\
Ceftazidime & $99.41 \pm 0.7567$ & $99.78 \pm 0.5612$ & $99.18 \pm 0.8714$ \\
Cefazoline & $100.14 \pm 0.9817$ & $100.16 \pm 0.8680$ & $100.4 \pm 0.6999$ \\
Ceftriaxone & $99.89 \pm 1.243$ & $100.87 \pm 0.8745$ & $100.67 \pm 0.7308$ \\
Cefuroxime & $99.31 \pm 1.242$ & $99.99 \pm 0.9167$ & $100.69 \pm 0.9595$ \\
\hline
\end{tabular}

* Mean of 6 replicate \pm SD.

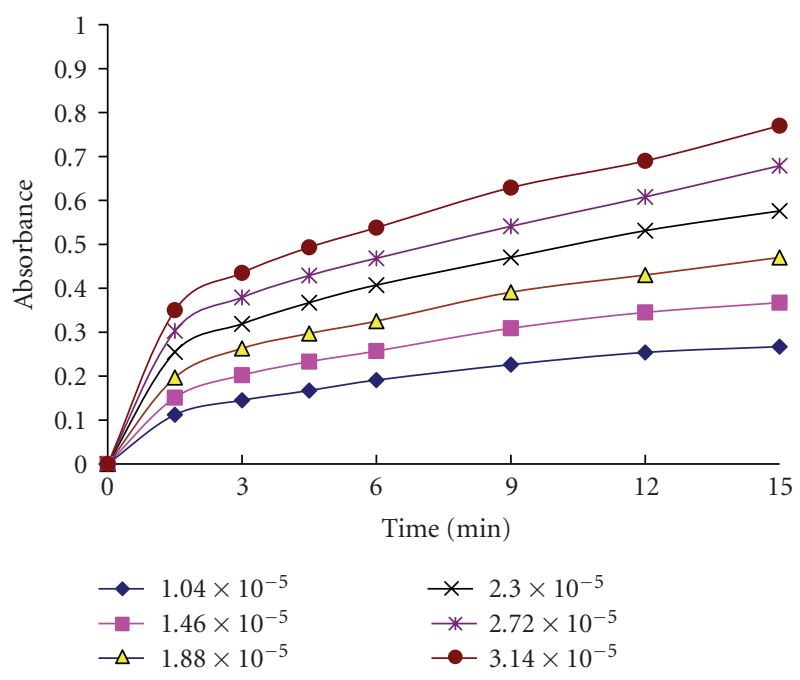

FIGURE 5: Absorption versus time for the reaction between cefotaxime (different molar concentrations) and $\mathrm{KMnO}_{4}(1.8 \times$ $\left.10^{-3} \mathrm{~mol} \mathrm{~L}^{-1}\right)$.

order of the reaction. The logarithmic form of the above equation is written as follows:

$$
\log v=\log \frac{\Delta A}{\Delta t}=\log K^{\prime}+n \log C .
$$

Regression analysis using the method of least square was performed to evaluate the slopes, intercepts, and correlation coefficient.

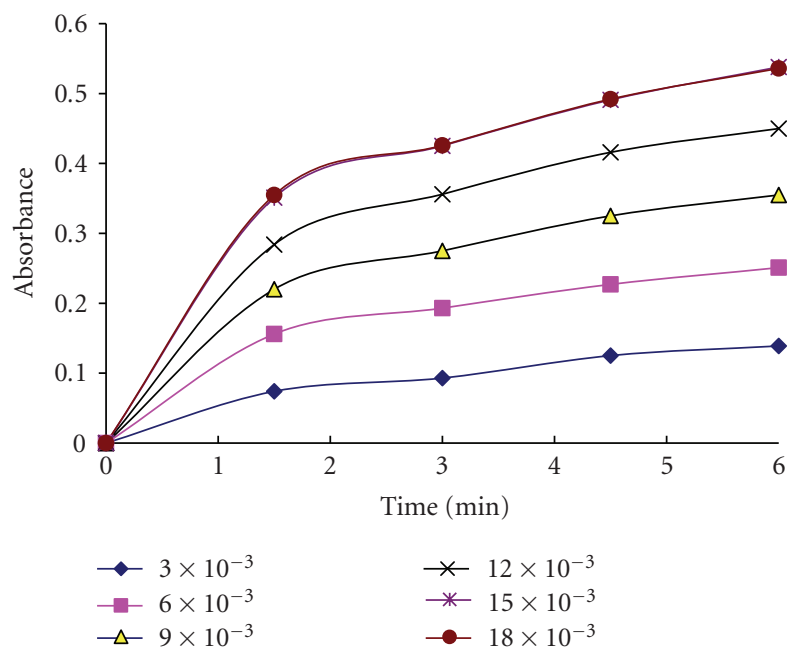

Figure 6: Absorption versus time for the reaction between cefotaxime $3.14 \times 10^{-5} \mathrm{~mol} \mathrm{~L}^{-1}$ and $\mathrm{KMnO}_{4}$ (different molar concentrations).

The analytical parameters and results of regression analysis are given in Table 2 . The value of $n(\approx 1)$ in the regression equation confirmed that the reaction of cephalosporins with the potassium permanganate was pseudo-first-order with respect to cephalosporins concentration. The limits of detection (LOD) were calculated and results obtained confirmed good sensitivity of the proposed method and consequently their capabilities to determine low amount of cephalosporins. 
3.6.2. Fixed Time Method. In this method, the absorbance of the reaction solution containing varying amount of cephalosporins was measured at preselected fixed time. Calibration plots of absorbance versus the concentration of cephalosporins at fixed time were established for each investigated cephalosporins. The regression equation, correlation coefficients, and detection limits are given in Table 3. The lowest detection limit was obtained at fixed time of 15 minutes. However the fixed time of 3 minutes showed a wider concentration range for quantification.

According to international conference of harmonization (ICH) guideline for validation of analytical procedures [42], the detection limit is not required to be part of validation procedure for assay. Therefore on the basis of wider concentration range and less time of analysis, the fixed time of 3 minutes was recommended for determination.

3.7. Validation of the Proposed Method. Concentration range [42] is established by confirming that the analytical procedure provides a suitable degree of precision, accuracy, and linearity when applied to the sample containing amount of analyte within or at the extreme of the specified range of the analytical procedure $[43,44]$. In this work, concentrations ranging from $7.8 \times 10^{-6} \mathrm{M}$ to $4.31 \times 10^{-5} \mathrm{M}$ were studied for the investigated drugs in the initial rate method and concentration ranging from 5 to $25 \mu \mathrm{g} \mathrm{mL}^{-1}$ were studied for the investigated drugs in the fixed time method (at preselected fixed time of 3 minutes). The whole set of experiments were carried out through this range to ensure the validation of the proposed procedure. Linear calibration graphs were obtained for all the studied drugs by plotting the logarithm of initial rate of the reaction versus logarithm of molar concentration of analyte in the sample (in initial rate method) within the specified range (Figure 7):

$$
\log v=\log \frac{\Delta A}{\Delta t}=\log K^{\prime}+n \log C \quad(\text { where } n \approx 1)
$$

or by plotting the absorbance of the studied drugs versus the drug concentration (in fixed time method) within the specified range (Figure 8).

Linearity was studied for both initial rate and fixed time method indicated by the values of correlation coefficient $(r)$ and determination coefficient $\left(r^{2}\right)$ for both method (Tables 2 and 3).

Accuracy [44] was checked at three concentration levels within the specified range, six replicate measurements were recorded at each concentration levels. The results were recorded as percentage recovery \pm standard deviation (Tables 4 and 5).

Precision [44] was checked at three concentration levels, eight replicate measurements were recorded at each concentration level. The results are summarized in (Table 6). The calculated relative standard deviation were all below $2.2 \%$ indicating excellent precision of the proposed procedure at both level of repeatability and intermediate precision.

Specificity and interference the proposed procedure was performed in visible region away from the UV-absorption

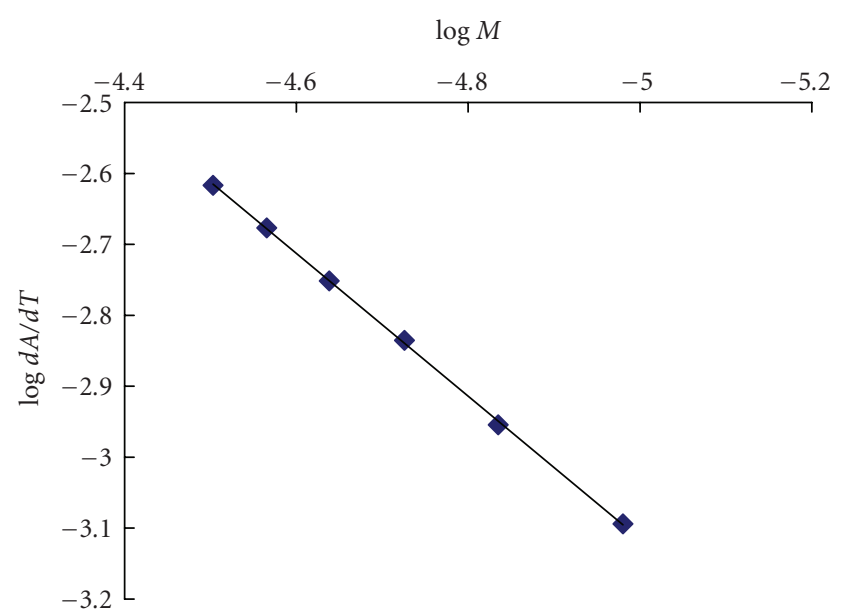

FIgURE 7: Calibration Plot of logarithm rate of the reaction against logarithm molar concentration of cefotaxime for initial rate method.

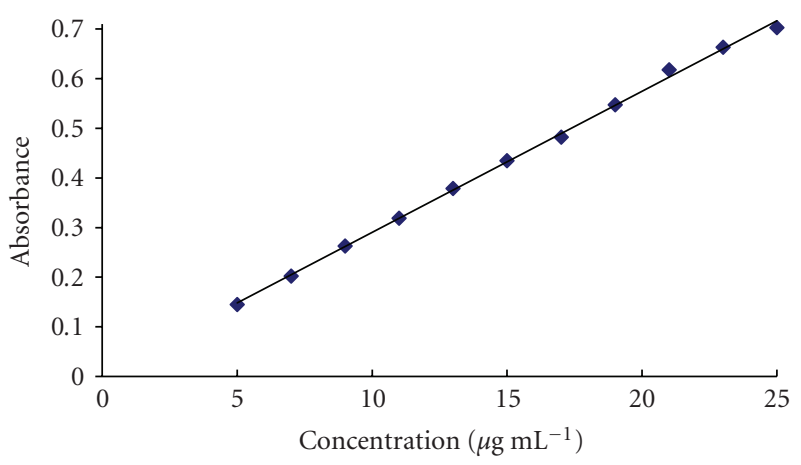

FIGURE 8: Calibration plot of absorbance versus the concentration of cefotaxime at preselected fixed time of 3 minutes.

region of investigated drugs (228-300 nm), and the interference by reducing sugars in tablets was eliminated by extraction with methanol prior to analysis. However interference was observed from L-arginine formulated with cephradine in velosef vial. Therefore, the proposed procedure could not be used for analysis of cephradine in presence of $\mathrm{L}$-arginine, except after separation by a suitable separation technique.

Limit of detection (LOD) [42] was calculated based on standard deviation of response and the slope of calibration curve [43]. The limit of detection was expressed as [44]

$$
\mathrm{LOD}=\frac{3 \sigma}{S}
$$

where $\sigma$ is the standard deviation of intercept. $S$ is the slope of calibration curve.

The results were summarized in (Tables 2 and 3 ) indicating good sensitivity of the proposed method. According to USP XXV validation guidelines [44], the calculated LOD values should be further validated by laboratory experiments. In our work, good results were obtained where the calculated drug concentration by LOD equations were actually detected in these experiments. 
TABLE 5: Evaluation of accuracy of the analytical procedure using fixed time method.

\begin{tabular}{lccc}
\hline Drug & & $\begin{array}{c}\text { Recovery \%* } \\
9.0 \mu \mathrm{gL}^{-1}\end{array}$ & $15.0 \mu \mathrm{g} \mathrm{mL} \mathrm{m}^{-1}$ \\
\hline Cefotaxime & $5.0 \mu \mathrm{g} \mathrm{mL}^{-1}$ & $100.98 \pm 0.8118$ & $100.75 \pm 0.6424$ \\
Cephapirin & $98.75 \pm 0.8183$ & $99.35 \pm 0.7414$ & $100.36 \pm .7051$ \\
Cephradine & $100.28 \pm 1.335$ & $101.87 \pm 0.9712$ & $100.58 \pm 0.8675$ \\
Cephalexin & $100.76 \pm 1.164$ & $100.09 \pm 0.5185$ & $100.77 \pm 0.6852$ \\
Ceftazidime & $98.59 \pm 0.839$ & $100.15 \pm 0.8789$ & $99.88 \pm 0.6548$ \\
Cefazoline & $99.66 \pm 1.485$ & $101.42 \pm 0.5617$ & $99.44 \pm 0.6155$ \\
Ceftriaxone & $99.63 \pm 1.262$ & $100.59 \pm 0.9242$ & $99.94 \pm 0.5474$ \\
Cefuroxime & $99.47 \pm 0.9185$ & $99.05 \pm 0.9773$ & $100.85 \pm 0.7630$ \\
\hline
\end{tabular}

* Mean of 6 replicate \pm SD.

TABLE 6: Evaluation of precision of the initial rate and fixed time methods of the proposed kinetic spectrophotometric method for determination of investigated cephalosporins.

\begin{tabular}{|c|c|c|c|}
\hline \multirow{2}{*}{ Drug } & \multirow{2}{*}{$\begin{array}{c}\text { Amount taken } \\
\left(\mu \mathrm{g} \mathrm{mL}^{-1}\right)\end{array}$} & \multicolumn{2}{|c|}{ Recovery $(\% \pm \mathrm{SD})$} \\
\hline & & Initial rate method & Fixed time method \\
\hline \multirow{3}{*}{ Cefotaxime } & 5 & $100.1 \pm 1.072$ & $99.82 \pm 0.7246$ \\
\hline & 9 & $99.88 \pm 0.6859$ & $100.9 \pm 0.7086$ \\
\hline & 15 & $99.95 \pm 0.5668$ & $100.6 \pm 0.6286$ \\
\hline \multirow{3}{*}{ Cephapirin } & 5 & $100.16 \pm 1.015$ & $100.29 \pm 1.144$ \\
\hline & 9 & $99.68 \pm 0.6840$ & $99.2 \pm 0.7160$ \\
\hline & 15 & $100.31 \pm 0.7624$ & $100.44 \pm 0.6225$ \\
\hline \multirow{3}{*}{ Cephradine } & 5 & $100.61 \pm 0.8049$ & $100.53 \pm 1.125$ \\
\hline & 9 & $99.94 \pm 0.5594$ & $101.84 \pm 0.9913$ \\
\hline & 15 & $99.70 \pm 0.6116$ & $100.51 \pm 0.9054$ \\
\hline \multirow{3}{*}{ Cephalexin } & 5 & $99.56 \pm 0.7435$ & $98.64 \pm 0.7306$ \\
\hline & 9 & $99.78 \pm 0.5811$ & $100.04 \pm 0.4796$ \\
\hline & 15 & $99.76 \pm 0.4575$ & $100.78 \pm 0.6091$ \\
\hline \multirow{3}{*}{ Ceftazidime } & 5 & $100.2 \pm 1.002$ & $99.53 \pm 1.309$ \\
\hline & 9 & $100.19 \pm 0.7958$ & $100.6 \pm 0.9820$ \\
\hline & 15 & $99.43 \pm 0.8901$ & $99.88 \pm 0.6205$ \\
\hline \multirow{3}{*}{ Cefazoline } & 5 & $99.88 \pm 1.066$ & $99.64 \pm 1.082$ \\
\hline & 9 & $101.07 \pm 0.8312$ & $101.45 \pm 0.4871$ \\
\hline & 15 & $100.44 \pm 0.7346$ & $99.46 \pm 0.5538$ \\
\hline \multirow{3}{*}{ Ceftriaxone } & 5 & $99.28 \pm 1.154$ & $99.34 \pm 0.9175$ \\
\hline & 9 & $99.99 \pm 0.8687$ & $100.54 \pm 0.8347$ \\
\hline & 15 & $100.76 \pm 0.6403$ & $99.98 \pm 0.4933$ \\
\hline \multirow{3}{*}{ Cefuroxime } & 5 & $100.19 \pm 1.19$ & $99.52 \pm 0.8834$ \\
\hline & 9 & $100.4 \pm 0.8276$ & $99.23 \pm 0.9490$ \\
\hline & 15 & $100.39 \pm 0.6692$ & $100.94 \pm 0.408$ \\
\hline
\end{tabular}

Limit of quantitation (LOQ) was calculated based on standard deviation of intercept and slope of calibration curve. In this method, the limit o quantitation is expressed as [44]

$$
\mathrm{LOQ}=\frac{10 \sigma}{S} .
$$

The results were summarized in (Tables 2 and 3 ) indicating good sensitivity of the proposed method. According to USP XXV validation guidelines [45], the calculated LOQ values should be further validated by laboratory experiments. In our work, good results were obtained where the calculated drug concentration by LOQ equations were actually quantitated in these experiments.

3.8. Application to Pharmaceutical Dosage Forms. The initial rate and fixed time methods of the proposed kinetic spectrophotometric method for determination of investigated cephalosporins have been tested on commercial pharmaceutical dosage forms. The concentration of investigated 
TABLE 7: Determination of studied drugs in their pharmaceutical dosage forms using initial rate and fixed time methods.

\begin{tabular}{|c|c|c|c|c|}
\hline \multirow{2}{*}{ Drug } & \multirow{2}{*}{ Pharmaceutical dosage form } & \multicolumn{2}{|c|}{ Proposed methods $\pm \mathrm{SD}(n=5)$} & \multirow{2}{*}{$\begin{array}{c}\text { Reported methods } \pm \mathrm{SD} \\
(n=5)\end{array}$} \\
\hline & & Initial rate & Fixed time & \\
\hline \multirow{3}{*}{ Cefotaxime } & \multirow{3}{*}{ Cefotax vials } & $100.67 \pm 0.9359$ & $99.98 \pm 1.146$ & \multirow{3}{*}{$100.58 \pm 0.9753$} \\
\hline & & $t=0.1423^{*}$ & $t=0.8914$ & \\
\hline & & $F=1.086^{*}$ & $F=1.382$ & \\
\hline \multirow{3}{*}{ Cephapirin } & \multirow{3}{*}{ Cefatrexyl vials } & $100.57 \pm 0.9274$ & $99.87 \pm 1.112$ & \multirow{3}{*}{$100.17 \pm 1.208$} \\
\hline & & $t=0.5901$ & $t=0.4193$ & \\
\hline & & $F=1.698$ & $F=1.180$ & \\
\hline \multirow{3}{*}{ Cephradine } & \multirow{3}{*}{ Velosef suspension } & $99.85 \pm 1.274$ & $99.4 \pm 1.699$ & \multirow{3}{*}{$99.89 \pm 1.190$} \\
\hline & & $t=0.1227$ & $t=0.5303$ & \\
\hline & & $F=1.346$ & $F=2.039$ & \\
\hline \multirow{3}{*}{ Cephradine } & \multirow{3}{*}{ Velosef capsuls } & $100.1 \pm 1.071$ & $100.56 \pm 0.6226$ & \multirow{3}{*}{$100.25 \pm 0.7994$} \\
\hline & & $t=0.2477$ & $t=0.6753$ & \\
\hline & & $F=1.793$ & $F=1.649$ & \\
\hline \multirow{3}{*}{ Cephalexin } & \multirow{3}{*}{ Ceporex vials } & $99.69 \pm 1.0$ & $100.43 \pm 0.918$ & \multirow{3}{*}{$100.19 \pm 0.9310$} \\
\hline & & $t=0.8248$ & $t=0.4069$ & \\
\hline & & $F=1.154$ & $F=1.027$ & \\
\hline \multirow{3}{*}{ Cephalexin } & \multirow{3}{*}{ Ceporex tablets } & $99.93 \pm 1.370$ & $100.06 \pm 1.647$ & \multirow{3}{*}{$99.98 \pm 1.112$} \\
\hline & & $t=0.06844$ & $t=0.08551$ & \\
\hline & & $F=1.518$ & $F=2.194$ & \\
\hline \multirow{3}{*}{ Ceftazidime } & \multirow{3}{*}{ Fortum vials } & $99.2 \pm 1.261$ & $99.74 \pm 1.212$ & \multirow{3}{*}{$99.78 \pm 0.6750$} \\
\hline & & $t=0.9192$ & $t=0.7738$ & \\
\hline & & $F=3.490$ & $F=3.222$ & \\
\hline \multirow{3}{*}{ Cefazoline } & \multirow{3}{*}{ Totacef vials } & $99.69 \pm 1.586$ & $99.35 \pm 1.059$ & \multirow{3}{*}{$99.25 \pm 1.379$} \\
\hline & & $t=0.4724$ & $t=0.1234$ & \\
\hline & & $F=1.321$ & $F=1.695$ & \\
\hline \multirow{3}{*}{ Ceftriaxone } & \multirow{3}{*}{ Ceftriaxone vials } & $99.92 \pm 1.292$ & $99.43 \pm 1.185$ & \multirow{3}{*}{$100.04 \pm 0.9742$} \\
\hline & & $t=0.1658$ & $t=0.8951$ & \\
\hline & & $F=1.760$ & $F=1.479$ & \\
\hline & & $100.31 \pm 1.091$ & $99.82 \pm 1.105$ & \\
\hline Cefuroxime & Zinnat vials & $t=0.0373$ & $t=0.8533$ & $100.33 \pm 0.7431$ \\
\hline & & $F=2.157$ & $F=2.209$ & \\
\hline
\end{tabular}

*Tabulated value at $95 \%$ confidence limit; $t=2.306$ and $F=6.388$.

cephalosporins was computed from its responding regression equations. The results of proposed method (initial rate and fixed time) were statistically compared with those of reported methods [3-5], in respect to accuracy and precision. The obtained mean recovery values were 99.2-100.67 $\pm 0.6226-$ $1.69 \%$ (Table 7), which ensures that there is no interference of other additives present in the studied formulations.

In the $t$ - and $F$-tests, no significant differences were found between the calculated and theoretical values of both the proposed and the reported methods at 95\% confidence level. This indicates good precision and accuracy in the analysis of investigated cephalosporins in pharmaceutical dosage forms.

\section{Conclusion}

The initial rate and fixed time methods can be easily applied for determination of investigated cephalosporins in pure and dosage forms that do not require elaborate treatment and tedious extraction of chromophore produced. The proposed method (initial rate or fixed time) is sensitive enough to enable determination of lower amounts of drug, these 
advantages encourage the application of proposed method in routine quality control of investigated cephalosporins in industrial laboratories. Finally our method provides advantages of improving selectivity, avoiding interference of colored and/or turbidity background of samples because it measures the increase in absorbencies with time against blank treated similarly.

\section{References}

[1] W. A. Remers and J. N. Delgado, Eds., Wilson and Gisvold's Textbook of Organic Medicinal and Pharmaceutical Chemistry, Lippincott-Raven, Philadelphia, Pa, USA, 10th edition, 1998.

[2] J. G. Hardman, L. E. Limbird, and A. G. Oilman, Goodman \& Gilman's the Pharmacological Basic of Therapeutics, McGrawHill, New York, NY, USA, 10th edition, 2001.

[3] G. A. Saleh, H. F. Askal, I. A. Darwish, and A.-N. A. ElShorbagi, "Spectroscopic analytical study for the chargetransfer complexation of certain cephalosporins with chloranilic acid," Analytical Sciences, vol. 19, no. 2, pp. 281-287, 2003.

[4] M. M. Ayad, A. A. Shalaby, H. E. Abdellatef, and H. M. Elsaid, "Spectrophotometric and atomic absorption spectrometric determination of certain cephalosporins," Journal of Pharmaceutical and Biomedical Analysis, vol. 18, no. 6, pp. 975-983, 1999.

[5] G. A. Saleh, H. F. Askal, M. F. Radwan, and M. A. Omar, "Use of charge-transfer complexation in the spectrophotometric analysis of certain cephalosporins," Talanta, vol. 54, no. 6, pp. 1205-1215, 2001.

[6] S. A. Patel, N. M. Patel, and M. M. Patel, "Spectrophotometric methods for the estimation of cephalexin in tablet dosage forms," Indian Journal of Pharmaceutical Sciences, vol. 68, no. 2, pp. 278-280, 2006.

[7] H. Salem and H. Askal, "Colourimetric and AAS determination of cephalosporins using Reineck's salt," Journal of Pharmaceutical and Biomedical Analysis, vol. 29, no. 1-2, pp. 347-354, 2002.

[8] M. Hefnawy, Y. El-Shabrawy, and F. Belal, "Spectrofluorometric determination of alpha-aminocephalosporins in biological fluids and pharmaceutical preparations," Journal of Pharmaceutical and Biomedical Analysis, vol. 21, no. 4, pp. 703-707, 1999.

[9] P. Gutiérez Navarro, A. El Bekkouri, and E. Rodríguez Reinoso, "Spectrofluorimetric study of the degradation of $\alpha$-amino $\beta$-lactam antibiotics catalysed by metal ions in methanol," Analyst, vol. 123, no. 11, pp. 2263-2266, 1998.

[10] F. A. Aly, M. M. Hefnawy, and F. Belal, "A selective spectrofluorimetric method for the determination of some $\alpha$ aminocephalosporins in formulations and biological fluids," Analytical Letters, vol. 29, no. 1, pp. 117-130, 1996.

[11] A. F. M. El Walily, A. Abdel-Kader Gazy, F. Belal, and E. F. Khamis, "Selective spectrofluorimetric determination of phenolic $\beta$-lactam antibiotics through the formation of their coumarin derivatives," Journal of Pharmaceutical and Biomedical Analysis, vol. 20, no. 4, pp. 643-653, 1999.

[12] L. I. Bebawy, K. El Kelani, and L. Abdel Fattah, "Fluorimetric determination of some antibiotics in raw material and dosage forms through ternary complex formation with terbium $\left(\mathrm{Tb}^{3+}\right)$, , Journal of Pharmaceutical and Biomedical Analysis, vol. 32, no. 6, pp. 1219-1225, 2003.

[13] Q. Ma, J. Yang, X. Wu, F. Huang, and L. Sun, "A selective fluorimetric method for the determination of some $\beta$-lactamic antibiotics," Analytical Letters, vol. 33, no. 13, pp. 2689-2699, 2000.

[14] A. Shalaby, "Simple HPLC method for the analysis of some pharmaceuticals," Journal of Liquid Chromatography and Related Technologies, vol. 21, no. 20, pp. 3161-3171, 1998.

[15] V. F. Samanidou, A. S. Ioannou, and I. N. Papadoyannis, "The use of a monolithic column to improve the simultaneous determination of four cephalosporin antibiotics in pharmaceuticals and body fluids by HPLC after solid phase extraction-a comparison with a conventional reversed-phase silica-based column," Journal of Chromatography B, vol. 809, no. 1, pp. 175-182, 2004.

[16] N. Ö. Can, G. Altiokka, and H. Y. Aboul-Enein, "Determination of cefuroxime axetil in tablets and biological fluids using liquid chromatography and flow injection analysis," Analytica Chimica Acta, vol. 576, no. 2, pp. 246-252, 2006.

[17] M. Becker, E. Zittlau, and M. Petz, "Residue analysis of 15 penicillins and cephalosporins in bovine muscle, kidney and milk by liquid chromatography-tandem mass spectrometry," Analytica Chimica Acta, vol. 520, no. 1-2, pp. 19-32, 2004.

[18] M. de Diego Glaría, G. G. Moscciati, and R. G. Ramos, "Determination of ceftriaxone in cerebrospinal fluid by ionpair liquid chromatography," Journal of AOAC International, vol. 88, no. 2, pp. 436-439, 2005.

[19] I. Baranowska, P. Markowski, and J. Baranowski, "Simultaneous determination of 11 drugs belonging to four different groups in human urine samples by reversed-phase high-performance liquid chromatography method," Analytica Chimica Acta, vol. 570, no. 1, pp. 46-58, 2006.

[20] S. Al-Rawithi, R. Hussein, D. A. Raines, I. AlShowaier, and W. Kurdi, "Sensitive assay for the determination of cefazolin or ceftriaxone in plasma utilizing LC," Journal of Pharmaceutical and Biomedical Analysis, vol. 22, no. 2, pp. 281-286, 2000.

[21] R. V. Oliveira, A. C. De Pietro, and Q. B. Cass, "Quantification of cephalexin as residue levels in bovine milk by highperformance liquid chromatography with on-line sample cleanup," Talanta, vol. 71, no. 3, pp. 1233-1238, 2007.

[22] Y.-M. Li, Y. Zhu, D. Vanderghinste, A. Van Schepdael, E. Roets, and J. Hoogmartens, "Micellar electrokinetic capillary chromatography for the separation of cefalexin and its related substances," Electrophoresis, vol. 20, no. 1, pp. 127-131, 1999.

[23] H.-H. Yeh, Y.-H. Yang, Y.-W. Chou, J.-Y. Ko, C.-A. Chou, and S.-H. Chen, "Determination of ceftazidime in plasma and cerebrospinal fluid by micellar electrokinetic chromatography with direct sample injection," Electrophoresis, vol. 26, no. 4-5, pp. 927-934, 2005.

[24] F. A. Aly, N. A. Alarfaffj, and A. A. Alwarthan, "Permanganatebased chemiluminescence analysis of cefadroxil monohydrate in pharmaceutical samples and biological fluids using flow injection," Talanta, vol. 47, no. 2, pp. 471-478, 1998.

[25] Y. Sun, Y. Tang, H. Yao, and X. Zheng, "Potassium permanganate-glyoxal chemiluminescence system for flow injection analysis of cephalosporin antibiotics: cefalexin, cefadroxil, and cefazolin sodium in pharmaceutical preparations," Talanta, vol. 64, no. 1, pp. 156-159, 2004.

[26] C. Thongpoon, B. Liawruangrath, S. Liawruangrath, R. A. Wheatley, and A. Townshend, "Flow injection chemiluminescence determination of cephalosporins in pharmaceutical preparations using tris (2,2' -bipyridyl) ruthenium (II)potassium permanganate system," Analytica Chimica Acta, vol. 553, no. 1-2, pp. 123-133, 2005.

[27] Y. Li and J. Lu, "Chemiluminescence flow-injection analysis of $\beta$-lactam antibiotics using the luminol-permanganate reaction," Luminescence, vol. 21, no. 4, pp. 251-255, 2006. 
[28] C. Thongpoon, B. Liawruangrath, S. Liawruangrath, R. A. Wheatley, and A. Townshend, "Flow injection chemiluminescence determination of cefadroxil using potassium permanganate and formaldehyde system," Journal of Pharmaceutical and Biomedical Analysis, vol. 42, no. 2, pp. 277-282, 2006.

[29] N. A. Alarfaj and S. A. Abd El-Razeq, "Flow-injection chemiluminescent determination of cefprozil using tris $\left(2,2^{\prime}\right.$ bipyridyl) ruthenium (II)-permanganate system," Journal of Pharmaceutical and Biomedical Analysis, vol. 41, no. 4, pp. 1423-1427, 2006.

[30] I. F. Jones, J. E. Page, and C. T. Rhodes, "The polarography of cephalosporin C derivatives," The Journal of Pharmacy and Pharmacology, vol. 20, supplement, p. 455, 1968.

[31] A. M. M. Ali, "Polarographic determination of cephradine in aqueous and biological media," Bioelectrochemistry and Bioenergetics, vol. 33, no. 2, pp. 201-204, 1994.

[32] G. V. S. Reddy and S. J. Reddy, "Estimation of cephalosporin antibiotics by differential pulse polarography," Talanta, vol. 44, no. 4, pp. 627-631, 1997.

[33] A. A. Abdel Gaber, M. A. Ghandour, and H. S. El-Said, "Polarographic studies of some metal(II) complexes with cephalosporins selected from the first generation," Analytical Letters, vol. 36, no. 6, pp. 1245-1260, 2003.

[34] A. Hilali, J. C. Jiménez, M. Callejón, M. A. Bello, and A. Guiraúm, "Electrochemical reduction of cefminox at the mercury electrode and its voltammetric determination in urine," Talanta, vol. 59, no. 1, pp. 137-146, 2002.

[35] S. R. Crouch, T. F. Cullen, A. Scheeline, and E. S. Kirkor, "Kinetic determinations and some kinetic aspects of analytical chemistry," Analytical Chemistry, vol. 70, no. 12, pp. 53-106, 1998.

[36] E. M. Hassan and F. Belal, "Kinetic spectrophotometric determination of nizatidine and ranitidine in pharmaceutical preparations," Journal of Pharmaceutical and Biomedical Analysis, vol. 27, no. 1-2, pp. 31-38, 2002.

[37] N. Rahman, N. A. Khan, and S. N. H. Azmi, "Kinetic spectrophotometric method for the determination of silymarin in pharmaceutical formulations using potassium permanganate as oxidant," Pharmazie, vol. 59, no. 2, pp. 112-116, 2004.

[38] N. Rahman, Y. Ahmad, and S. N. H. Azmi, "Kinetic spectrophotometric method for the determination of norfloxacin in pharmaceutical formulations," European Journal of Pharmaceutics and Biopharmaceutics, vol. 57, no. 2, pp. 359-367, 2004.

[39] I. A. Darwish, "Kinetic spectrophotometric methods for determination of trimetazidine dihydrochloride," Analytica Chimica Acta, vol. 551, no. 1-2, pp. 222-231, 2005.

[40] P. Job, Advanced Physicochemical Experiments, Oliner and Boyd, Edinburgh, UK, 2nd edition, 1964.

[41] P. Job, Annales de Chimie, vol. 6, p. 97, 1936.

[42] International Conference on Harmonization, "ICH harmonized tripartite guideline-text on validation of analytical procedures," Federal Register, vol. 60, p. 11260, 1995.

[43] "Q2A: text on validation of analytical procedure," in Proceedings of International Conference on Harmonization (ICH '94), Geneva, Switzerland, 1994.

[44] "Q2B: validation of analytical procedure, methodology", in Proceedings of International Conference on Harmonization (ICH '96), Geneva, Switzerland, 1996.

[45] The United States Pharmacopoeia XXV and NF XX, American Pharmaceutical Association, Washington, DC, USA, 2002. 


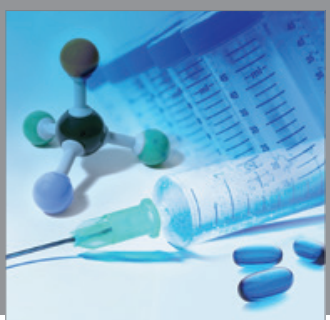

International Journal of

Medicinal Chemistry

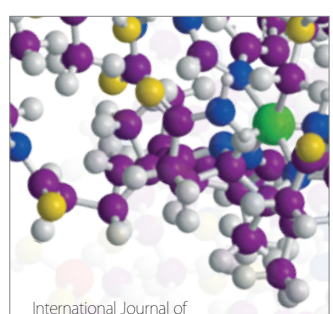

Carbohydrate Chemistry

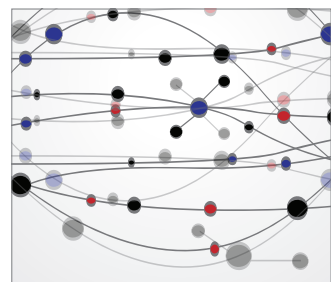

The Scientific World Journal
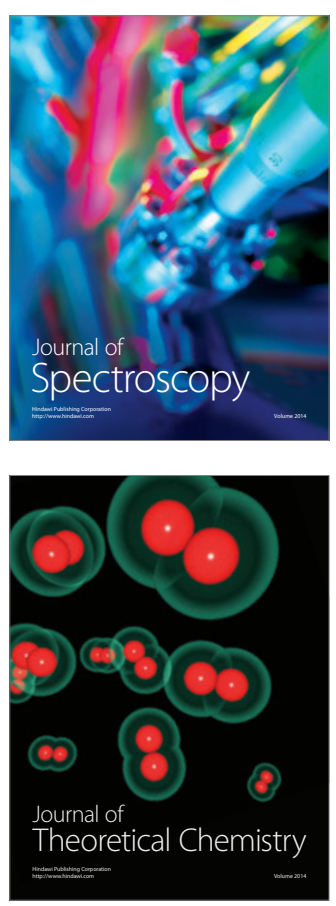
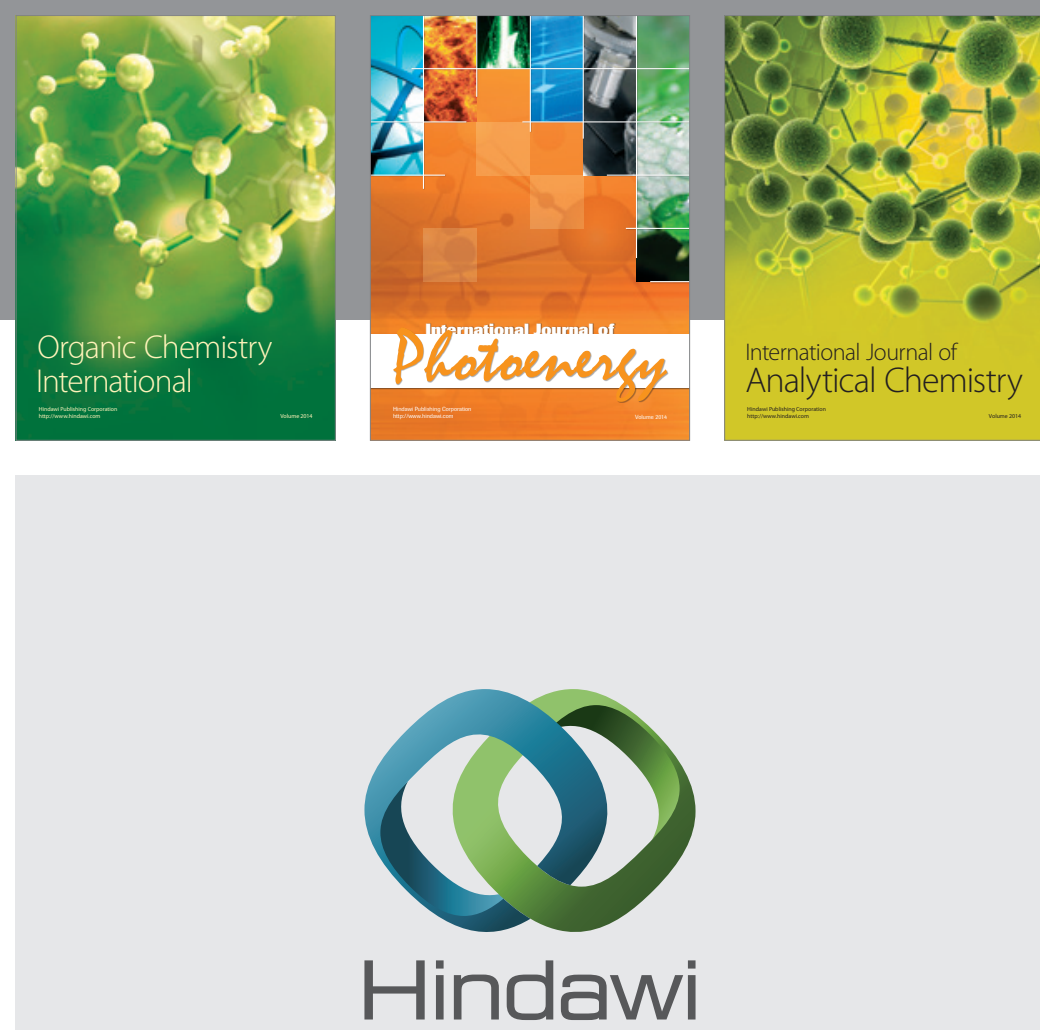

Submit your manuscripts at

http://www.hindawi.com
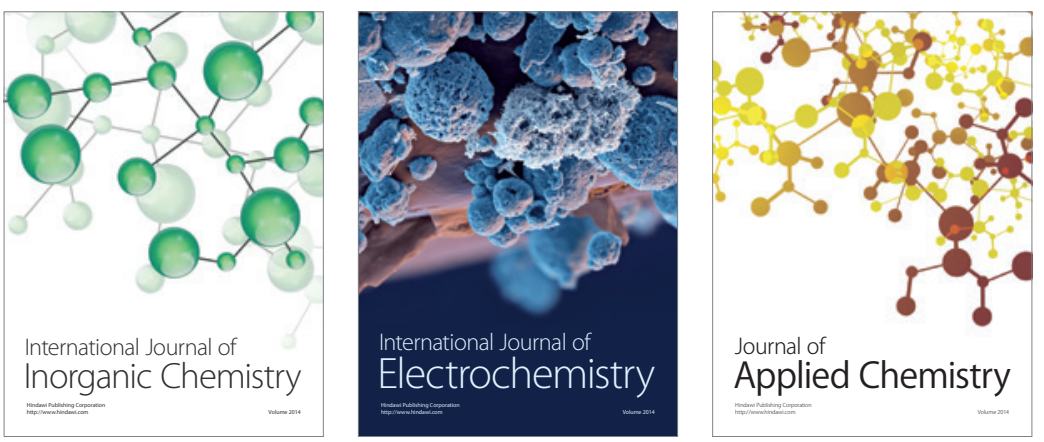

Journal of

Applied Chemistry
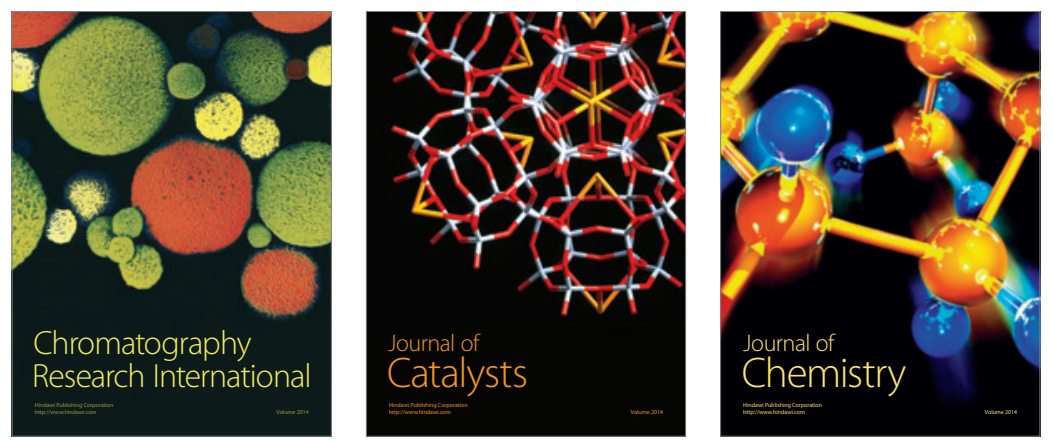
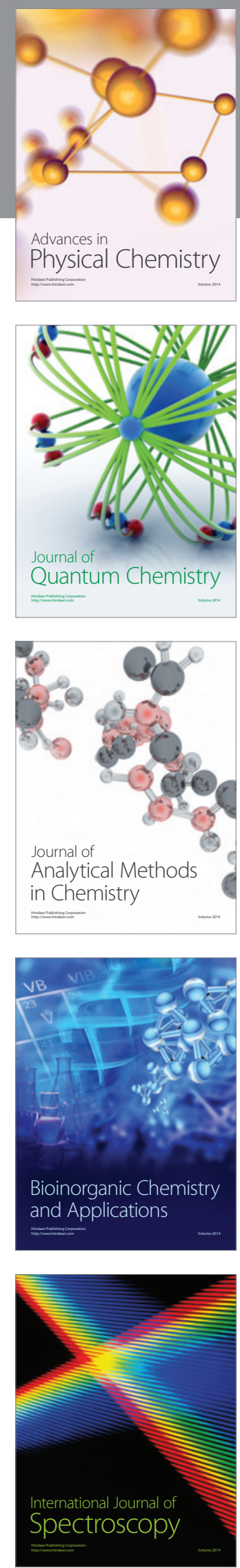